\title{
Global Comparative Study on REDD+ story of change CIFOR's science on wetlands for Indonesian measurement, reporting and verification and forest reference emission level development
}

Rupesh K Bhomia, Sandy Nofyanza, Tobias Thürer, Erin O'Connell and Daniel Murdiyarso

\section{Key messages}

- Tropical forested wetlands, including peatlands and mangroves, provide critical environmental services and store 3-5 times more carbon than other tropical forests.

- However, because these ecosystems are under significant pressure from unsustainable land-use practices, they must be credited in the national forest monitoring and measurement mechanism and integrated into the national policy agenda.

- In January 2016, the Government of Indonesia submitted a forest reference emission level (FREL) to the United Nations Framework Convention on Climate Change (UNFCCC) secretariat, and is currently in the process of finalizing its second FREL.

- To achieve the intended improvement in the FREL, CIFOR has played an active role by co-producing relevant data and knowledge products, building capacity among key personnel and stakeholders, and creating a platform for communication, engagement and outreach at national and international levels.

\section{Setting the scene: Taking stock of wetlands}

Tropical forested wetlands, including peatlands and mangroves, are important landscapes that play a critical role in sustaining life on earth. Beyond their aesthetic value, these ecosystems provide critical ecological functions and environmental services that benefit upland and oceanic ecosystems and communities, and they play an important role in global climate mitigation strategies, storing 3-5 times more carbon than other tropical forests (Donato et al. 2011, Murdiyarso et al. 2015). This carbon can be lost to the atmosphere when these landscapes are disturbed or degraded. Approximately 47 percent of the world's tropical peatlands (about 21 million ha) and 23 percent of its mangroves (about 3 million ha) are found in Indonesia, where these ecosystems have faced significant pressure from unsustainable land-use practices since the 1980s (Murdiyarso et al. 2012). It is therefore imperative that these tropical wetlands are properly credited in the national forest monitoring and measurement mechanism and that efforts are made to integrate them into the national policies.
In January 2016, the Government of Indonesia submitted a forest reference emission level (FREL) to the United Nations Framework Convention on Climate Change (UNFCCC) secretariat. It was formulated according to the best available data, knowledge and technical capacity at that time. The reference level considered activities such as deforestation, forest degradation and peat decomposition and was set at $0.57 \mathrm{GtCO}_{2} \mathrm{e} \mathrm{yr}^{-1}$ using $1990-2012$ as its reference period. This FREL is being used as the benchmark for evaluating REDD+ performance against actual emissions during the 2013-2020 implementation period. The Government of Indonesia is currently finalizing its second FREL, to be submitted to UNFCCC in 2021

Under the Global Comparative Study on REDD+ (GCS REDD+), CIFOR aims to improve the mechanisms and practices for measuring and managing carbon stocks of forests and wetlands in the tropics. Together with key ministries and organizations, CIFOR works to improve Indonesia's FREL and its associated measurement, reporting and verification (MRV) system by (i) supporting inclusion in national reporting of drivers of deforestation, forest degradation and under-represented forest dynamics through 
improved recognition of processes which underpin carbon sequestration (e.g. forest growth) as well as losses (e.g. peatland fires) in high-carbon reservoirs like mangrove and peatlands (ii) reducing uncertainties in activity data and emission factors; (iii) the inclusion of non- $\mathrm{CO}_{2}$ greenhouse gases, such as methane and nitrous oxide; and (iv) enhancing the predictability of trends of activity data and dynamics of emission factors by modelling approaches.

This 'story of change', which was coordinated by CIFOR's Research to Impact evaluation team, describes an effort to verify the achievement of high-level outcomes from CIFOR's research and engagement activities to support the Government of Indonesia in estimating and managing carbon stocks of tropical forest and wetland landscapes. The analysis presented here is based on a theory of change,' a review of secondary data including reports, government policies and media stories, consultations with the lead researchers in the country, evidence collected by an independent consultant through interviews with 10 key stakeholders, and a sense-making workshop to discuss findings from these interviews.

\section{Interventions}

With the ultimate goal of contributing to greater protection of the high-carbon-value ecosystems of mangroves and peatlands, as well as increasing benefits to local communities in the form of REDD+ result-based payments, CIFOR has engaged in a variety of research, knowledge exchange, capacity building and engagement activities.

To help refine Indonesia's national FREL and MRV system, CIFOR has produced actionable knowledge and innovations in the form of new datasets, ${ }^{2}$ published analyses on land-use sector emissions at regional and national levels (see for example Kauffman et al. 2016, Sasmito et al. 2016, Hergoualc'h et al. 2018, Sasmito et al. 2019), and continues to promote the development and integration of 'blue carbon' into the national policy agenda. CIFOR has organized several events that have brought scientists and policymakers together to share new knowledge about greenhouse gas accounting in wetlands to improve the FREL and the national MRV system. For example, during one such high-profile event - the Blue Carbon Summit in June 2018 - high-ranking officials from various Government of Indonesia departments highlighted the role of scientific dialogue, facilitated by ongoing CIFOR research on coastal blue carbon ecosystems, in the accounting of carbon gains and losses in these important ecosystems. Presently,

\footnotetext{
1 The narrative in this infobrief describes the theory of change impact pathway. A graphical depiction is provided in Figure 1 at the end of this report.

2 Relevant datasets from GCS REDD+, as well as wetlands-related datasets from the Sustainable Wetlands Adaptation and Mitigation Program, are available at https://data.cifor.org/dataverse/s

3 https://events.globallandscapesforum.org/blue-carbon-summit/
}

blue carbon has become part of the broader low-carbon development strategy laid out in the 2020-2024 National Mid-Term Development Plan (Government of Indonesia 2020).

CIFOR is also uniquely positioned to facilitate knowledgesharing across national borders. One example is the 2019 Blue Carbon Workshop ${ }^{4}$ in Hanoi, Vietnam, which provided training and capacity building for government officials and academics from 13 countries in Asia-Pacific in calculating and reporting carbon stock changes. This led to improvements in the preparation of national communications, such as biannual update reports (BURs) and Nationally Determined Contributions, or NDCs (Pham and Le Thi 2019). Scientific knowledge and lessons learned on improving FREL and MRV systems within Indonesia are shared with the governments of the Democratic Republic of Congo and the Republic of Congo as an ongoing process via the International Tropical Peatlands Center (ITPC), a centre of excellence for tropical peatland research established in 2018 and co-facilitated by CIFOR, the United Nations Environment Programme, and the Food and Agriculture Organization of the United Nations (FAO).

In addition to CIFOR's contribution to wetlands science, the direct involvement of CIFOR experts in policy formulation contributed to an immediate and substantial impact on the implementation and design of REDD+ in Indonesia beyond FREL and MRV development, such as the inter-ministerial coordination effort to address forest and peat fires in the country. Most recently, the Government of Indonesia through the National Development Planning Agency (Bappenas) established the Strategic Coordination Team for Wetlands Management. ${ }^{5}$ As part of this multi-stakeholder working group, CIFOR scientists will continue building on the long history of collaboration, knowledge-sharing and direct advisory support in the pursuit of sustainable wetland management in Indonesia beyond research and academic writing.

Another critical aspect of the national REDD+ monitoring and evaluation is local participation. GCS REDD+ research aimed to contribute to enriching participatory MRV (or PMRV) knowledge and literature as a starting point to enable communities' participation in REDD+ PMRV. From its research, CIFOR learned that PMRV could be built through a harmonized policy directive from national to local level (districts and villages) and continuous encouragement from local leaders (Ekowati et al. 2016), and that it could be more feasible if the government were to use a tiered system that accommodates different reporting templates across levels (Boissiere et al. 2017). More importantly, PMRV may have a better chance of success and be more sustainable in a community with clear access and rights to the forest (Hawthorne and Boissière 2014). This opens the possibility for PMRV to be embedded in ongoing community-based

4 https://www2.cifor.org/blue-carbon-ndc-workshop/

5 This working group was established through the Head of Bappenas' decree no. KEP.89/M.PPN/HK/10/2020. 
forest management initiatives (Boissière et al. 2014), such as the agrarian reform (Tanah Objek Reforma Agraria, or TORA) and the social forestry scheme. This would not only ensure smoother data collection and reporting, but also the implementation of social safeguards so that REDD+ benefits reach local people.

The early REDD+ projects have been a successful laboratory, providing important lessons for future forestbased climate mitigation actions (see Sills et al. 2014, Angelsen et al. 2018). In 2019, CIFOR organized a field trip with 11 journalists from across Southeast Asia to a private ecosystem restoration concession known as the Katingan Mentaya Project in Central Kalimantan, where they were taken to a peatland ecosystem for an immersive experience and better understanding of issues at the landscape level. During this excursion, CIFOR and partners highlighted the importance of promoting alternative sustainable livelihoods for local communities to encourage better forest stewardship, as demonstrated in the REDD+ project. Activities across the 120,000 ha of peatlands within Katingan Mentaya Project include participatory mapping and planning, as well as various community development programs that support local livelihoods. ${ }^{6}$

\section{Ongoing research and progress}

Countries throughout the world struggle to improve accuracy and reduce uncertainty in calculations and reporting of data under REDD+ schemes. CIFOR's ongoing efforts have successfully supported the Government of Indonesia to ensure that MRV is carried out uniformly and consistent with UNFCCC reporting guidelines. The aim is to refine these processes in terms of improved data collection capacity and reduced uncertainty in determination of activity data and emission factors, as well as inclusion of data from unaccounted sinks and sources. By generating momentum, CIFOR aims to encourage the adoption of these practices at various implementation levels.

\section{Inclusion of wetlands}

The way the government conducts forest monitoring and evaluation has improved over time in line with technological advancements; however, efforts are continuing to further increase the quality and accuracy of data being collected and its reporting. As noted by a senior lecturer and researcher from Universitas Lampung, "In the past, deforestation data was only available in a visual version [analogue or tabular]. Now it has developed into a mix between digital and analogue/tabular. The data is now becoming increasingly clear, whereas before there used to be a lot of [grey areas] in it." The Indonesian Ministry of Environment and Forestry (KLHK) remains committed to

6 More details on the Katingan Mentaya Project are available at the 2020 online workshop series, Transforming REDD+ in Indonesia: https:// www.cifor.org/event/transforming-redd-in-indonesia/ further enhancing the accuracy of the 2016 FREL with the support of CIFOR and all its partners, for instance by improving data collection on mangroves and peatlands to obtain better emission factors, as well as by including other REDD+ activities, such as forest conservation and sustainable forest management (Ministry of Environment and Forestry 2018). The respondent went on to explain, "People are increasingly critical nowadays about data quality, [which prompted] the ministry to start conducting accuracy assessments. Enhancement of carbon stocks and sustainable forest management are also being taken into consideration [in the next iteration of FREL]. We will also take into account aspects related to peatland fires and mangroves. CIFOR is currently promoting awareness around issues facing mangroves." A similar statement was also voiced by a highlevel Bappenas and Ministry of Environment and Forestry official, who added, "[We now know that] rich carbon stock in mangroves is mostly found in the soil and belowground biomass. This is a crucial research input from our research and development unit and CIFOR. Therefore, we [KLHK] are considering including [aspects pertaining to] mangroves for the second FREL."

The Government of Indonesia is currently drafting a roadmap to have high-carbon reservoirs like mangroves included in the national reporting system, complementary to aspects pertaining to peat decomposition that were included in 2016 FREL. This process is ongoing and was spearheaded by the Wetlands Management Team under Bappenas. According to a senior Bappenas official, the approaches to preserving wetlands ecosystems are laid out in the 2019 Low-Carbon Development Indonesia framework, which has been mainstreamed into the 20202024 National Mid-Term Development Plan.

Separately, improvement in emission factors is expected from the availability of detailed land cover analyses in several types of land use classes (see for example Kauffman et al. 2016, Sasmito et al. 2016). Interviewed stakeholders expect this to emerge over time as the work and support from CIFOR continue. As acknowledged by a top official from the Ministry of Environment and Forestry, "We have held discussions with CIFOR to improve the quality of emission factors. We have asked CIFOR to prepare and assist us with Tier 2 emission factors - now we are still using Tier 1 emission factors. We understand that after the publication of the 2013 Intergovernmental Panel on Climate Change guidelines, there is plenty of research regarding peatland emission factors, so it is very possible for us to set Tier 2 emission factors, or Tier 3 if possible. [This is because] most of the research on peatland emission factors does in fact come from Indonesia. The same goes for mangroves; we hope CIFOR can assist us with higher-quality emission factors, particularly from mangrove ecosystems that we have discussed."

Several interviewees confirmed that different stakeholders, particularly scholars and policymakers, now have a better understanding of the relevance of so-far unaccounted or unreported carbon sinks, and the necessity to design 
policies and activities accordingly. The earliest example of policy change, as highlighted by a senior Bappenas official, is the enactment of the 2011 forest and peatland moratorium, which was made permanent in 2019.? Another indicator of change, as discussed by a highranking Ministry of Environment and Forestry official, is the recent transformation of the Peatland Restoration Agency into the Peatland and Mangrove Restoration Agency, as well as the inclusion of mangrove planting as a priority in the national economic recovery program (Program Pemulihan Ekonomi Nasional, or PEN).

\section{Improvement in measurement, reporting and verification capacity}

The technical MRV system and capacity for measuring forest area change and forest-related emissions in Indonesia are developed commensurate with REDD+ implementation in the country. Nationally, Indonesia ranks "very high" on MRV administrative capacity and its technical method ownership (Ochieng et al. 2016, 47). It is also deeply institutionalized, as a sufficient number of actors and resources were mobilized to put forest MRV development in national policy discourses (Ochieng et al. 2018, 3). In terms of data, Indonesia is considered to have "very good" use of both remote sensing and national forest inventory for forest monitoring (Nesha et al. 2021, 13). Through GCS REDD+ and other relevant programs such as the Sustainable Wetlands Adaptation and Mitigation Program, CIFOR contributed to the enhancement of such capacity among Government of Indonesia scientists and policymakers through national, subnational, and local-level trainings and workshops. One high-ranking Ministry of Environment and Forestry officer commented on the impact of this contribution: "[one of the most] concrete impacts of CIFOR's research and engagement is the increase in our capacity. For example, assessing the transparency, accuracy, consistency, completeness and comparability [criteria] against our FREL document was new for us, and it helped us to see how transparent, accurate, consistent and comparable our document is to other documents. We also gained knowledge related to uncertainty calculations; we knew about the technicalities of it but had never implemented it." Another high-level Ministry of Environment and Forestry official acknowledged the current "advanced level of capacity" while emphasizing the need for continuous research support: "we are pretty advanced from the technical capacity point of view, but at this time we are limited only to

7 Several interviewed stakeholders made the comment, and World Resources Institute (WRI) analysis shows that out of 2.8 million hectares of mangrove forests in Indonesia, only 1.85 million ha are inside forest moratorium areas, while the remaining of 0.9 million ha of mangrove forests are outside moratorium areas. Given the mangroves' importance for the provision of many ecosystem services and climate change mitigation, having a moratorium policy extended to all mangrove forests would be beneficial. The extended mangrove moratorium policy would further lead to the protection of primary mangrove forests that fall into areas zoned for cultivation (called Kawasan Budidaya). emissions from drained peatlands... we continue to need research inputs to further improve our emission factors to reach a higher reporting tier."

However, the technical MRV capacities across different agencies and governmental levels remain unevenly distributed (Ochieng et al. 2018). Some subnational jurisdictions are relatively more advanced than others. For example, the Forest Management Unit of East Kalimantan, the pilot province for the jurisdictional REDD+ initiative under the Forest Carbon Partnership Facility's Carbon Fund scheme, has been equipped with trainings and capacity building and is "ready to carry out [activities regarding] measurement/calculations of land cover change in their working area", according to an MRV specialist from the Regional Council for Climate Change (DDPI). In this case, the country benefitted from support from numerous research and/or non-governmental organizations that work across the archipelago.

Overall, PMRV remains an idea that needs to be developed and implemented. According to a senior researcher from the Ministry of Environment and Forestry's Forestry and Environmental Research Development and Innovation Agency, PMRV is underdeveloped because Indonesia's MRV system was designed as a top-down system. Nevertheless, the government is trialling ways to have a bottom-up MRV system in the future, as explained by one respondent: "In the case of the Forest Carbon Partnership Facility's Carbon Fund in East Kalimantan, [some] activities related to monitoring and reporting emissions and land cover change will be carried out by local communities, the Forest Management Unit and private sector actors in a participatory manner. They will report directly to the provincial government through the Environmental Agency." For ease of reporting, the government of East Kalimantan has established a multi-stakeholder measurement, monitoring and reporting working group tasked with accelerating the reporting process from subnational to national entities. ${ }^{8}$ This upcoming PMRV system will be linked to aspects pertaining to REDD+ safeguards and benefit-sharing, thereby ensuring local communities are properly credited and rewarded for the emission reduction activities conducted at local/site level.

The recent announcement of the first round of resultsbased payments to Indonesia by the Norwegian Government and the Green Climate Fund suggests that Indonesia is now recognized as a relevant and capable recipient of international climate change mitigation funding. The ongoing jurisdictional REDD+ initiatives also demonstrate the capacity of national and subnational governments in undertaking forest-based climate

8 The Measurement, Monitoring, and Reporting Working Group was established through the East Kalimantan Governor Decree (SK) no. 660.2/K.511/2019. 
mitigation activities to help achieve global climate goals. However, apart from the ongoing Forest Carbon Partnership Facility's Carbon Fund implementation, the government's commitment to protecting highcarbon wetland ecosystems will not be enough without appropriate benefit-sharing mechanisms for local communities. Two interviewees expect this to emerge over time: "the government is preparing the indicators and criteria to determine who will get the payment. Because this is a nation-wide scheme, the government will provide two mechanisms. The first is a proposal-based payment, so there will be an open call for those who want to participate in emission reductions throughout the country. The second is top-down: the central government will provide incentives for subnational jurisdictions that have contributed significantly towards emission reductions." At this stage, however, "the government is still only aiming to compensate parties who have succeeded in reducing emissions in the past."

\section{Addressing deforestation and degradation drivers beyond the forestry sector}

As a consequence of the current momentum, better integration and consideration of forest and agricultural sector mitigation options are expected to be achieved. For example, linking REDD+ policies and practices in the landscape with emerging initiatives from agriculture sectors - such as paludiculture and social forestry in peatlands - is one approach. However, as one Forestry and Environmental Research Development and Innovation Agency researcher explained, these remain a challenging feat, as "we are still seeking the way to manage/utilize peatlands naturally without draining them - a method that is still not widely understood by the community". Other examples are integrating REDD+ with climate-smart agriculture, and private sector sustainable supply chain initiatives (Pacheco et al. 2018). Several interviewees expect this to emerge over time, particularly a pilot in Jambi Province, for a jurisdictional REDD+ initiative known as the BioCarbon Fund. According to a top Ministry of Environment and Forestry official, this initiative seeks to apply climatesmart agriculture or intensification to halt forest conversion, as well as to influence the spatial planning process, with further emphasis on the importance of jurisdictional or landscape approaches for a comprehensive and integrated development planning: "in my opinion, this jurisdictional/landscape approach is the right approach to be developed in the future in the context of REDD+. So, not only are we protecting the forest, we are also addressing the drivers of deforestation so that the forest will be preserved by itself." CIFOR is currently assisting the Sustainable Districts Association (Lingkar Temu Kabupaten Lestari, or LTKL) to help its member districts transition to sustainable economic development following a jurisdictional approach.

\section{Conclusions and lessons learned}

This infobrief illustrates our efforts to verify the achievement of high-level outcomes from CIFOR's research, capacity building and various other engagement activities to support the Government of Indonesia in estimating and managing carbon stocks of tropical forest and wetland landscapes. This is an attempt to bring together such evidence to demonstrate the difference (impact) that CIFOR's concerted efforts have made on national and subnational policies and also to reflect on the direction of the trajectory we are on.

The evidence presented here suggests that emissionreduction activities, and public policies and regulations are now better targeted towards emission hotspots and areas with high potential for enhanced removals. This becomes evident, for example, in the current drafting of the roadmap for the management of wetlands for mangrove and peatland forests, or in the recent inauguration of the Peatland and Mangrove Restoration Agency, which institutionalizes mangroves in the government administration structure, as well as enhanced inter-ministerial coordination on how to address forest fires in areas with a high propensity for fire.

For long-lasting meaningful change, ongoing engagement and dialogue are very important, including the inclusion of embedded CIFOR researchers in the change process. CIFOR's activities have striven to strike a balance between action-oriented research, engagement of all relevant stakeholders, and communicating the new lessons extensively, including with the members of the Government of Indonesia who are most directly responsible for effecting change. Publishing our findings in scientific journals as well as policy briefs, which are more easily accessible, has helped garner support and mobilize resources for institutionalizing new and advanced processes of accounting, monitoring and reporting forest change and associated carbon dynamics. CIFOR is dedicated to continue its research and engagement activities, informed by sound science and demand-driven objectives.

\section{Acknowledgements}

This research is part of CIFOR's Global Comparative Study on REDD+ (www.cifor.org/gcs). The funding partners that have supported this research include the Norwegian Agency for Development Cooperation (Norad), the International Climate Initiative (IKI) of the German Federal Ministry for the Environment, Nature Conservation and Nuclear Safety (BMU), the United States Agency for International Development (USAID) and the CGIAR Research Program on Forests, Trees and Agroforestry (CRP-FTA), with financial support from the donors contributing to the CGIAR Fund. 


\section{ACTIONABLE KNOWLEDGE \&} INNOVATIONS

Research outputs in the form of national and regional-scale datasets and academic articles on land-use emissions to help refine national forest reference emission levels

Large-scale events aimed at disseminating new knowledge on greenhouse gas accounting in wetlands to improve FREL and the national MRV system

Trainings and outreach aimed at Government of Indonesia officials/agencies to improve technical capacity for calculating and reporting carbon stock changes

Outreach and engagement with local or indigenous communities to enable participation in REDD+ MRV and FRE development

\section{Sphere of Control}

The Sphere of Control includes activities that are conducted by the project and outputs produced by it. It hence usually ends on output level, where the research project can exert direct control.

\section{STAKEHOLDER}

Coordinating Ministry of Maritime and Investment Affairs

Ministry of Environment and Forestry

Peatland and Mangrove Restoration Agency

National Development Planning Agency (Bappenas)

Ministry of Agriculture

National Institute for Aeronautics and Space

Forestry and Environmental Research Development and Innovation Agency, Ministry of Environment and Forestry

Subnational forest and environmental government agencies

Universities and research institution

NGOS

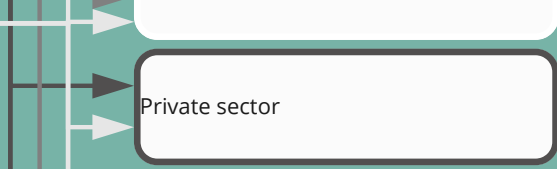

Forest Management Units

Community and producer associations

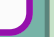

achieves OUTCOMES

New information/data is used for reference emissions level

development and evaluation of

change in emissions over time (e.g.

One Map, support in developing

Indonesian National Carbon

Accounting System)

Improvement in accuracy of

determination of sources and sinks

of emissions, through inclusion of

other REDD+ activities (i.e.

conservation and enhancement of

forest carbon stock, sustainable

forest management) in reference

emissions level development

Improvement in peatland emission

factors based on detailed land cover

analyses in several types of peatland

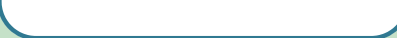

Improved knowledge/technical capacity of local or indigenous communities in partaking REDD+ MRV

\section{Enhanced capacity of the}

Government of Indonesia

officials/agencies at national,

subnational and local levels via

trainings and workshops to improve

technical capacity for calculating and

reporting carbon stock changes

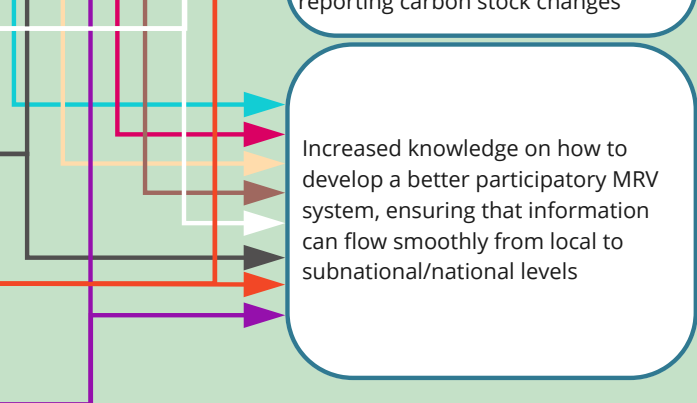

Sphere of Influence

The Sphere of Influence covers where the project aims to influence or bring about change via the actors the project works with and through. Projects results targeted/achieved in this sphere typically refer to outcomes and high-level outcomes.

\section{Figure 1. Theory of Change describing the impact pathway for GCS REDD+ work on wetlands for Indonesian MRV and} FREL development

Source: Authors'illustration 


$\begin{array}{lllll}\text { HIGH-LEVEL OUTCOMES } & \begin{array}{l}\text { which are } \\ \text { expected to } \\ \text { lead to }\end{array} & \text { INTERMEDIARY } & \begin{array}{l}\text { thereby } \\ \text { contributing } \\ \text { IN }\end{array} & \text { ULTIMATS } \\ \text { EXPECTED IMPACTS }\end{array}$

Enhanced national capacity for

measuring forest area change and forestrelated emissions

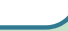

Inclusion of wetlands, including highcarbon reservoirs like mangrove and peatland ecosystems, in national reporting

Forest measurement, reporting and verification is carried out uniformly and accurately, consistent with UNFCCC reporting guidelines (includes all greenhouse gas emissions and sinks)

Different stakeholders better understand the relevance of so-far unattended carbon sinks and the necessity to design policies and activities accordingly

Increased participation and acceptance by local communities as well as govt line depts (resource managers) who are entrusted to safeguard natural resources, including people responsible for national forest monitoring and REDD+ performance reporting (national and subnational)

Government of Indonesia continues to receive financial support for

implementing REDD+ policies as it makes consistent improvements in carbon accounting and MRV systems

Emission reduction activities, public policies and regulations better targeted to emission hotspots and areas with high potential for enhanced removals

More integration and consideration of forest and agriculture sector mitigation options by linking REDD+ policies and practices in landscape with climate-smart agriculture

Better protection of high carbon value ecosystems (mangroves and peatlands) and increased benefits (Results Based Payments) to local Due to the improved measurements communities.
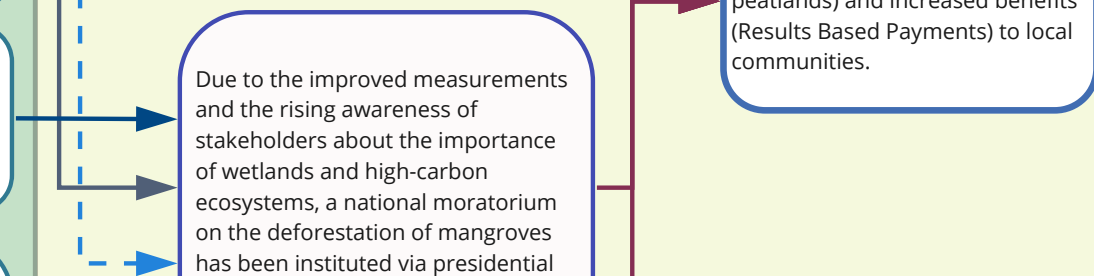

stakeholders about the importance of wetlands and high-carbon ecosystems, a national moratorium on the deforestation of mangroves

$\rightarrow$ has been instituted via presidential decree

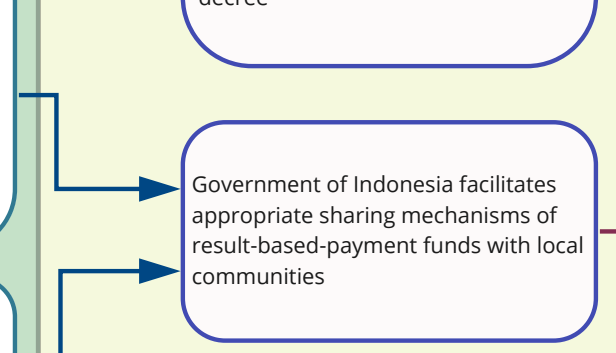

\section{Sphere of Interest}

The Sphere of Interest models indirect changes that fall outside the direct influence of the project. These changes result in new uncertainties, which may manifest themselves as outcomes or changes in the social, economic or environmental conditions. These changes result in new uncertainties, where new research entry points and questions are identified. Projects results targeted/achieved in this sphere typically refer to intermediary impact and the expected ultimate impact level. 


\section{References}

Angelsen A, Martius C, De Sy V, Duchelle AE, Larson AM, Pham $T$. (eds.) 2018. Transforming REDD+: Lessons and new directions. Bogor, Indonesia: CIFOR. https://doi.org/10.17528/cifor/007045

Boissière M, Felker L, Beaudoin G, Bong IW, Hawthorne SD, Depuy WH, Ekowati D, Farida L, Hofstee C, Praputra AV, et al. 2014. Estimating carbon emissions for REDD+: the conditions for involving local people. Perspective. Paris, France: CIRAD and CIFOR. https://www.cifor.org/knowledge/publication/5208/

Boissiere M, Herold M, Atmadja S and Sheil D. 2017. The feasibility of local participation in measuring, reporting and verification (PMRV) for REDD. PLoS One 12: e0176897. https://doi.org/10.1371/journal. pone.0176897

Donato DC, Kauffman JB, Murdiyarso D, Kurnianto S, Stidham M and Kanninen M. 2011. Mangroves among the most carbon-rich forests in the tropics. Nature Geoscience 4: 293-297. https://doi. org/10.1038/ngeo1123

Ekowati D, Hofstee C, Praputra AV and Sheil D. 2016. Motivation matters: Lessons for REDD+ participatory measurement, reporting and verification from three decades of child health participatory monitoring in Indonesia. PLoS One 11: e0159480. https://doi. org/10.1371/journal.pone.0159480

Government of Indonesia. 2020. Rencana Pembangunan Jangka Menengah Nasional Tahun 2020-2024. Jakarta: Government of Indonesia.

Hawthorne SD and Boissière M. 2014. Literature review of participatory measurement, reporting and verification (PMRV). Working Paper 152. Bogor, Indonesia: CIFOR. https://doi. org/10.17528/cifor/005030

Hergoualc'h K, Atmadja SS, Carmenta R, Martius C, Murdiyarso D and Purnomo H. 2018. Managing peatlands in Indonesia: Challenges and opportunities for local and global communities. Infobrief. Bogor, Indonesia: CIFOR. https://doi.org/10.17528/cifor/006449

Kauffman JB, Arifanti VB, Basuki I, Kurnianto S, Novita N, Murdiyarso D, Donato DC and Warren MW. 2016. Protocols for the measurement, monitoring, and reporting of structure, biomass, carbon stocks and greenhouse gas emissions in tropical peat swamp forests. Working Paper 221. Bogor, Indonesia: CIFOR. https://doi.org/10.17528/cifor/006429

Ministry of Environment and Forestry (Indonesia). 2018. Indonesia report on REDD+ performance. Jakarta, Indonesia: Directorate General of Climate Change, Ministry of Environment and Forestry.

Murdiyarso D, Kauffman JB, Warren M, Pramova E and Hergoualc'h K. 2012. Tropical wetlands for climate change adaptation and mitigation: Science and policy imperatives with special reference to Indonesia. Working Paper 91. Bogor, Indonesia: CIFOR. https:// doi.org/10.17528/cifor/003806

Murdiyarso D, Purbopuspito J, Kauffman JB, Warren MW, Sasmito $\mathrm{SD}$, Donato DC, Manuri S, Krisnawati $\mathrm{H}$, Taberima $\mathrm{S}$ and Kurnianto S. 2015. The potential of Indonesian mangrove forests for global climate change mitigation. Nature Climate Change 5: 1089-1092. https://doi.org/10.1038/nclimate2734

Nesha MK, Herold M, De Sy V, Duchelle AE, Martius C, Branthomme A, Garzuglia M, Jonsson O and Pekkarinen A. 2021. An assessment of data sources, data quality and changes in national forest monitoring capacities in the Global Forest Resources Assessment 2005-2020. Environmental Research Letters 16. https://doi. org/10.1088/1748-9326/abd81b

Ochieng RM, Visseren-Hamakers IJ, Arts B, Brockhaus M and Herold M. 2016. Institutional effectiveness of REDD+ MRV: Countries progress in implementing technical guidelines and good governance requirements. Environmental Science and Policy 61: 42-52. https://doi.org/10.1016/j.envsci.2016.03.018

Ochieng RM, Arts B, Brockhaus M and Visseren-Hamakers IJ. 2018. Institutionalization of REDD+ MRV in Indonesia, Peru, and Tanzania: Progress and implications. Ecology and Society 23. https://doi.org/10.5751/ES-09967-230208

Pacheco P, Bakhtary H, Camargo M, Donofrio S, Drigo I and Mithöfer D. 2018. The private sector: Can zero deforestation commitments save tropical forests? In: Angelsen A, Martius C, De Sy V, Duchelle $A E$, Larson AM and Pham TT. (eds.) Transforming REDD+: Lessons and new directions. Bogor, Indonesia: CIFOR. https://www.cifor. org/knowledge/publication/7073

Pham $\Pi$ and Le Thi TT. 2019. Incorporating blue carbon into Nationally Determined Contributions: Current status, opportunities and challenges of 13 Asia-Pacific countries. Infobrief. Bogor, Indonesia: CIFOR. https://doi.org/10.17528/cifor/007554

Sasmito SD, Taillardat P, Clendenning J, Friess DA, Murdiyarso D and Hutley LB. 2016. Carbon stocks and fluxes associated with land-use and land-cover change in mangrove ecosystems: A systematic review protocol. Working Paper 211. Bogor, Indonesia: CIFOR. https://doi.org/10.17528/cifor/006225

Sasmito SD, Taillardat P, Clendenning JN, Cameron C, Friess DA, Murdiyarso D and Hutley LB. 2019. Effect of land-use and landcover change on mangrove blue carbon: A systematic review. Global Change Biology 25: 4291-4302. https://doi.org/10.1111/ gcb.14774

Sills EO, Atmadja SS, De Sassi C, Duchelle AE, Kweka DL, Resosudarmo IAP and Sunderlin WD. (eds.) 2014. REDD+ on the ground: A case book of subnational initiatives across the globe. Bogor, Indonesia: CIFOR. https://doi.org/10.17528/cifor/005202

\begin{tabular}{|l|l|l|l|l} 
The CGIAR Research Program on Forests, Trees and Agroforestry (FTA) is the world's largest research for \\
development program to enhance the role of forests, trees and agroforestry in sustainable development \\
and food security and to address climate change. CIFOR leads FTA in partnership with Bioversity \\
International, CATIE, CIRAD, ICRAF, INBAR and TBI. \\
PROGRAM ON \\
Forests, Trees an's work is supported by the CGIAR Trust Fund: cgiar.org/funders/ \\
Agroforestry
\end{tabular}

